\title{
Rare orbital apex spindle cell proliferation presenting with subacute blindness in a child
}

\author{
Yongya Kim, ${ }^{1}$ Denise Malicki, ${ }^{2}$ Michael Levy, ${ }_{1}^{3}$ John Ross Crawford ${ }^{4,5}$
}

'Department of Neurosciences, University of California San Diego, San Diego, California, USA

${ }^{2}$ Pathology, Rady Children's Hospital University of California San Diego, San Diego,

California, USA

${ }^{3}$ Neurosurgery, University of California San Diego, San Diego, California, USA

${ }^{4}$ Neurosciences and Pediatrics, University of California San Diego, San Diego, California, USA

${ }^{5}$ Department of Neurosciences and Pediatrics, University of California San Diego and Rady Children's Hospital, San Diego, California, USA

\section{Correspondence to} Dr John Ross Crawford; jrcrawford@ucsd.edu

Accepted 16 July 2021

Check for updates

(c) BMJ Publishing Group Limited 2021. No commercial re-use. See rights and permissions. Published by BMJ.

To cite: Kim Y, Malicki D, Levy M, et al. BMJ Case Rep 2021;14:e245118. doi:10.1136/bcr-2021245118

\section{DESCRIPTION}

A 13-year-old boy with no significant medical history presented with 6 months of progressive visual loss in the right eye. Ophthalmological examination demonstrated a right-sided afferent pupillary defect, absent vision and a pale optic nerve. CT revealed a lytic lesion involving the right orbital apex centred in the right anterior clinoid process of the sphenoid (figure 1A). MRI demonstrated a contrast-enhancing orbital apex mass with encasement of the right optic nerve and extension along the posterior medial aspect of the right-sided Meckel's cave (figure 1B,C). MRI of the entire spine was normal. Based on the neuroimaging features, the radiographical differential diagnosis included Tolosa-Hunt syndrome, Langerhans' cell histiocytosis, lymphoma, leukaemia, schwannoma and meningioma. Neurological examination was otherwise normal. The patient underwent surgical resection where permanent sections (figure 2) demonstrated compact and trabecular bone focally invaded by connective tissue of low cellularity with spindle cells in a haphazard arrangement and increased vascularity, with focal bony resorption. The spindle cells showed bland nuclei with inconspicuous nucleoli and fibrillar amphophilic cytoplasm. Immunohistochemistry demonstrated immunoreactivity to CD34 and smooth muscle actin (SMA) while negative to epithelial membrane antigen (EMA), S100 and D2-40. Together, these findings resulted in a histopathological diagnosis of benign spindle cell proliferation. The patient underwent a near total resection and followed by surveillance neuroimaging without evidence of recurrence more than 5 years following diagnosis (figure 1D). Unfortunately, the patient never had recovery of vision in the right eye.

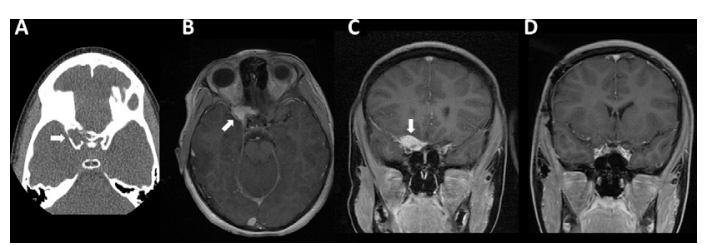

Figure 1 Neuroimaging findings of spindle cell proliferation. CT revealed a lytic lesion (arrow) involving the right orbital apex centred in the right anterior clinoid process of the sphenoid (A). MRI revealed a contrastenhancing orbital apex mass with encasement of the right optic nerve and a questionable additional mass along the posterior medial aspect of the right Meckel's cave (arrow) (B, C). Five years post resection, there is no evidence of recurrent disease (D).

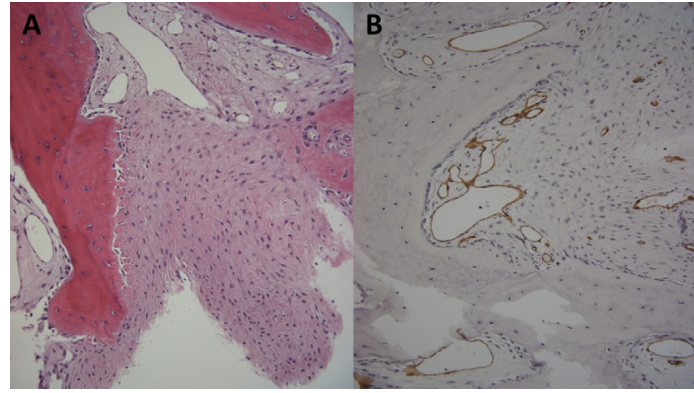

Figure 2 Histological features of spindle cell proliferation. Neuropathology demonstrated compact and trabecular bone focally invaded by connective tissue of low cellularity with spindle cells in a haphazard arrangement and increased vascularity, with focal bony resorption. The spindle cells showed bland nuclei with inconspicuous nucleoli and fibrillar amphophilic cytoplasm (A). Immunohistochemistry demonstrated immunoreactivity to CD34 (B) and smooth muscle actin while negative staining for epithelial membrane antigen, S100 and D2-40.

Spindle cell proliferations of the head and neck include a wide variety of neural, myofibroblastic, muscle, fibroblastic, vascular, epithelial, odontogenic and miscellaneous tumours. ${ }^{1}$ They are classified as benign, intermediate or malignant depending on their behaviours. More common differentials of spindle cell tumours include dermatofibrosarcoma protuberans (DFSP), solitary fibrous tumour, spindle cell lipoma and malignant peripheral nerve sheath tumour (MPNST). DFSP is a low-grade intermediate tumour consisting of spindle-shaped tumour cells infiltrating fat lobules with a collagenous stroma exhibiting immunoreactivity to CD34. Solitary fibrous tumour is an uncommon benign tumour with fibrous stroma and branching thin-walled vessels exhibiting immunoreactivity to CD34, EMA, SMA, CD99, Bcl-2 and STAT6. Spindle cell lipoma is a benign tumour consisting of bland spindle cells with mature adipose tissue in a background of thick ropey collagen exhibiting immunoreactivity to CD $34 .^{2}$ MPNST is a rare high-grade malignant tumour arising from peripheral nerves and exhibiting immunoreactivity to S100 and Leu-7. Immunohistochemical markers are integral in classifying and diagnosing spindle cell tumours. CD34 immunostaining is typically positive for solitary fibrous tumour, gastrointestinal stromal tumours, DFSP, epithelioid sarcoma, spindle cell lipoma, synovial sarcoma and vascular tumours. However, immunoreactivity to such markers is not entirely specific, and does not always 
confirm the diagnosis. ${ }^{2}$ As such, spindle cell tumours remain a diagnostic challenge in the clinic. Our case of a rare spindle cell proliferation of the orbital apex in a child with subacute vision loss, treated with surgery alone highlights the challenging nature of spindle cell tumour diagnosis and expands the differential diagnosis of benign orbital apex lesions of childhood.

\section{Learning points}

Orbital apex lesions have an expanded differential diagnosis by neuroimaging and require tissue for diagnosis.

- New and traditional immunohistochemical staining methods are integral in the diagnosis of spindle cell tumours.

- Spindle cell tumours pose a diagnostic challenge in the clinic.
Contributors YK was responsible for the design and writing of the manuscript. DM was responsible for the design and writing of the manuscript. ML was responsible for the design and writing of the manuscript. JRC was responsible for the design and writing of the manuscript.

Funding The authors have not declared a specific grant for this research from any funding agency in the public, commercial or not-for-profit sectors.

Competing interests None declared.

Patient consent for publication Parental/guardian consent obtained.

Provenance and peer review Not commissioned; externally peer-reviewed.

\section{REFERENCES}

1 Surbhi, Metgud R, Naik S, et al. Spindle cell lesions: a review on immunohistochemical markers. J Cancer Res Ther 2017:13:412-8.

2 Wei S, Henderson-Jackson E, Qian X, et al. Soft tissue tumor immunohistochemistry update: illustrative examples of diagnostic pearls to avoid pitfalls. Arch Pathol Lab Med 2017; 141:1072-91

Copyright 2021 BMJ Publishing Group. All rights reserved. For permission to reuse any of this content visit https://www.bmj.com/company/products-services/rights-and-licensing/permissions/

BMJ Case Report Fellows may re-use this article for personal use and teaching without any further permission.

Become a Fellow of BMJ Case Reports today and you can:

- Submit as many cases as you like

- Enjoy fast sympathetic peer review and rapid publication of accepted articles

- Access all the published articles

- Re-use any of the published material for personal use and teaching without further permission

Customer Service

If you have any further queries about your subscription, please contact our customer services team on +44 (0) 2071111105 or via email at support@bmj.com.

Visit casereports.bmj.com for more articles like this and to become a Fellow 